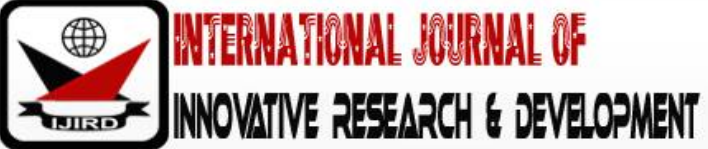

ISSN 2278 - 0211 (Online)

\section{Association between Continuing Nursing Education (CNE) and Quality of Patients' Services}

\author{
Rozina Amir Ali \\ Senior Nursing Instructor, Department of School of Nursing, Saifee Burhani, Pakistan
}

\begin{abstract}
:
Continue Nursing Education (CNE) is very important in order to improve quality care of patients, A Descriptive Crosssectional Study was conducted (Questionnaire based study) to determine the effectiveness of continue nursing education in overall impact of patient condition, the study shows that most of the health care professional believes that in order to provide better quality care continuous nursing education plays a vital role, not only for the benefits of patient but for the professional grooming of health care professional as well .
\end{abstract}

Keywords: Continuous nursing education, quality care, professionalism

\section{Introduction}

In today's global world, quality of patient service has become an important focus for healthcare system. Healthcare system has been researching on initiatives to address challenges related to quality of patient services, such as inadequate technology driven infrastructure, lack of oversight and accountability mechanism, lack of implementation of rules \& regulations and limited newly nursing education opportunities. Continuing nursing education is part of the process of lifelong learning that all doctors undertake from medical College until retirement and has traditionally been viewed by the medical profession in terms of updating their knowledge.

CNE is widely recognized all over the world with the perception to strengthen healthcare system, especially quality service delivery to patients. However, the responsibility of CNE has never been properly carried by some health providers. For example, institution such as PMDC, Sindh nursing board, Nursing Universities and Medical institutions have not shown and shared interest formerly or in formerly on implementation of CNE.

Today's advance world attributed as the world of knowledge. The innovation solutions in the world of medical science emphasis on knowledge, attitude and practices/ skill. One may acquire knowledge in the field of medicine, yet the skill and attitude is an ongoing process to have continuous \& adaptive acquisition of new information/ knowledge, attitude and practices/ skill in order to flourish steadiness, quality \& competency in practice. The concept is to drive and develop new knowledge with already existing knowledge to maximize the impact of patients' services. It is noteworthy that medical experts, medical institutions with the help of regulatory authorities to integrate and implement CME as an integral part of quality service delivery as the system demands a long term and lifelong learning approach.

\subsection{Aim of the Study}

The aim of this study is to evaluate the impact of continue nursing education of nurses in the hospital services.

\section{Literature Review}

It has been observed that nurses almost share their expectation of the work environment according to their career stage relatively to their age (Sheri Price 1 and Carol Reichert) .1 Early career nurses need to work more and participate in continuous medical education to improve their knowledge and upgrade skills .2 If we want to retain mid and late career nurses there is a need to improve their professional skills and give continue training and education in order to grow professionally .3Educational and interactive activities for health care professional are very essential for evaluating skills and knowledge to prevent from disease of patients (Schmalenberg, et al. 2008).The nurses who is working at critical care areas have a very high skill knowledge as compare to theoretical knowledge and only continue education can enhance their theoretical .4Nurses should updated their professional knowledge and skills by attending multiple session in continue education services (Witt 2011) For improve quality of services it has been observed that nurses should updated their skills and knowledge on continuous basis .5. There are certain barriers observed while having having continuous nursing education and it could only be improved if there is a proper scheduling and encourage nurse managers to give their support to sterh then the continuous nursing education .6 


\subsection{Problem Statement}

Professional undergraduate nursing education programmers share the goal of preparing competent graduates who will successfully make the transition to the world of professional nursing practice. Furthermore, society demands continued professional accountability for competence in an era of exponential knowledge proliferation and technological change. One way to meet this demand is for every practicing professional to engage in continuing professional nursing education. If professional nurses are to maximize continuous learning, they need to be able to manage and monitor their own learning. This means that professional nurses engaged in continuous learning should have the ability to be selfdirected. The use of problem-based learning (PBL) as an instructional methodology in undergraduate nursing curricula has been identified as one way to facilitate the development of nursing students' abilities to become self-directed in learning. The theoretical links between PBL and self-directed learning are discussed.

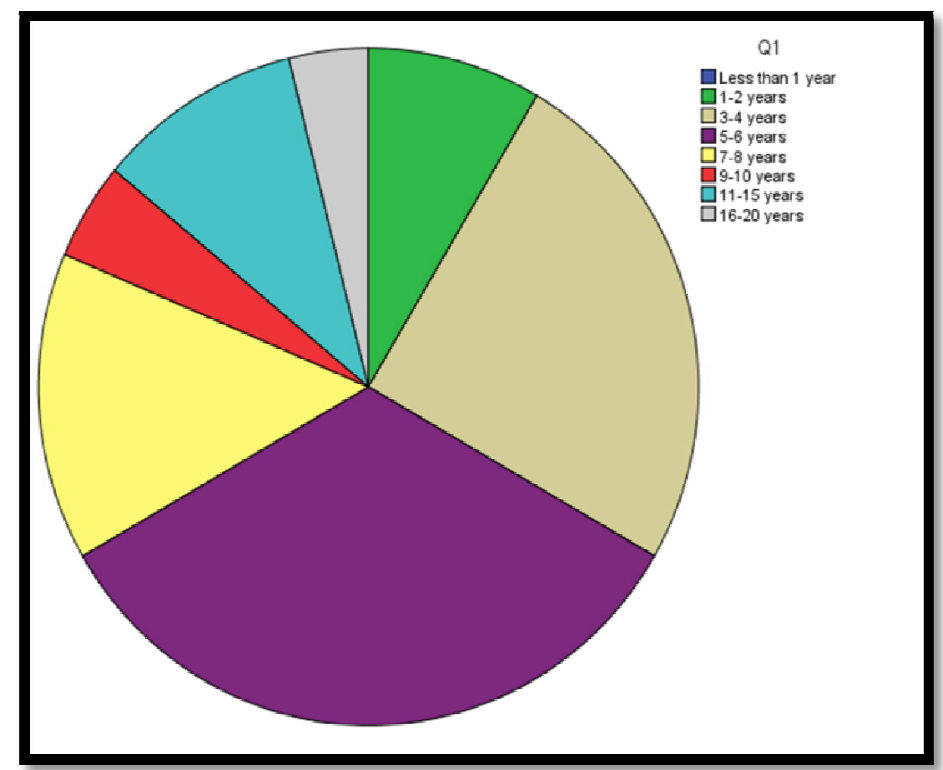

Figure 1: Years of Experience of Participants' in Healthcare Setting

\section{Methodology}

3.1. Study Design

Descriptive Cross-sectional (Questionnaire based study)

\subsection{Study Setting}

Multicenter Study

\subsection{Sampling Technique}

Simple Random Sampling

\subsection{Inclusion Criteria}

Health care professionals and nursing students aged 18 or above.

\subsection{Exclusion Criteria}

- Non-consenting individuals

- Any individual unable to understand English language

\section{Results}

A total of 137 subjects were enrolled in this study. The mean age of the participants was $29.91 \pm 5.80$. The years of experience of participants' in healthcare setting has been shown in Figure. Upon asking if CME actively promotes improvements in healthcare system, 67.9\% (93/137) strongly agreed with the statement. Similarly, 65.7\% (90/ 137) were strongly of the opinion that CME is beneficial for healthcare staff to promote lifelong learning process. On statement that CME improves healthcare staff's professional competence, mostly $61.3 \%$ (84/137) strongly agreed. Likewise, 59.1\% (82/137) subjects believed that CME helps to improve patients care and satisfaction. Lastly, $61.3 \%$ (84/137) subjects strongly agreed with the statement that CME promotes accountability and transparency towards patients' care.

\section{Discussion}

Continuing medical education is defined as strategic knowledge infusion process to enhance the skills, knowledge, attitude and practice of healthcare staff. Sessions, conferences, workshops and seminars offer a persistent source of 
professional grooming and empowerment.1 continuing medical education planner should adapt suitable programmer cater the requirements of individuals to enhance and uplift the efficacy of their practices.2

Healthcare staffs are at the forefront of patient care and therefore their knowledge requires incessant advancement. In this regard, investment on continuing medical education for healthcare staff through seminars, workshops and conferences is crucial for their competency in any healthcare organization. Research demonstrates that continuing medical education is a fundamental part of professionalism and could perform as an establishing component in healthcare staff function. American Medical Institute communicated that expert and knowledgeable healthcare staff should be skilled for the future of healthcare. Apparently, expert healthcare staffs bring elevation in quality care in hospital setting. Hence, the hindrances and challenges of healthcare staff education should be elucidated.1, 3

Perhaps, training of healthcare staffs in hospitals could reform their professional practices, while it could also lead to reduction in medical errors, patient complaints and occupational hazards. It will eventually increase patient satisfaction rate and will optimize treatment and quality care indicators in healthcare organization. Several studies have showed positive results on the standpoint of healthcare staffs regarding the effectiveness of continuing medical education on clinical competence, self-confidence and awareness and skills. Global studies have proved that continuing medical education is efficient in improving healthcare quality.4-6

The present study evaluated whether continuing medical education leads to overall improvement in healthcare staffs learning process and healthcare quality. Most of the study subjects were of the opinion that continuing medical education improves healthcare quality, lifelong learning of healthcare professionals, professional competence, patient care and promotes accountability and transparency towards patients' care. Inspection and feedback of continuing medical education regarding the behavioral modifications in continuing medical education participants is indispensable to evaluate the effectiveness of the continuing medical education programme.2

\section{Conclusion}

In conclusion, the present study suggests that healthcare staff believe that continuing medical education have an important role in grooming not only the knowledge and practice of healthcare staff but also the quality care in any healthcare organization.

\section{References}

i. Eslamian J, Moeini M, Soleimani M. Challenges in nursing continuing education: A qualitative study. Iranian journal of nursing and midwifery research. 2015; 20(3):378-86.

ii. Bahador H, Pazooki A, Kabir A. Effectiveness of continuing medical education considering participant's idea in Iran University. JPMA The Journal of the Pakistan Medical Association. 2010; 60(6):435-9.

iii. Ni C, Hua Y, Shao P, Wallen GR, Xu S, Li L. Continuing education among Chinese nurses: a general hospital-based study. Nurse education today. 2014;34(4):592-7.

iv. Giarelli E, Ruttenberg J, Segal A. Continuing education for nurses in the clinical management of autism spectrum disorders: results of a pilot evaluation. Journal of continuing education in nursing. 2012; 43(4):169-76.

v. Farzi S, Shahriari M, Farzi S. Exploring the challenges of clinical education in nursing and strategies to improve it: A qualitative study. Journal of education and health promotion. 2018; 7:115.

vi. Waddell DL. The effects of continuing education on nursing practice: a meta-analysis. Journal of continuing education in nursing. 1991;22(3):113-8. The Importance of Continuing Professional Development to Career Satisfaction and Patient Care: Meeting the Needs of Novice to Mid- to Late-Career Nurses throughout Their Career Span

vii. (Kovner, C.T.; Brewer, C.S.; Fairchild, S.; Poornima, S.; Kim, H.; Djukic, M. newly licensed RNs' characteristics, Work attitudes, and intentions to work. Am.J. Nurs. 2007, 107, 58-70. [CrossRef] [PubMed])

viii. (Armstrong-Stassen, M. Human resource management strategies and the retention of older RNs.Nurs. Leadersh. 2005, 18, 50-64. [CrossRef])effect of educational program on nurses, knowledge and skills about oral care for traumatized patients mervatanwarabd el-azizd.n.sc, the department of critical care nursing, faculty of nursing, assuit university

ix. Translating Continuing Professional Development Education to Nursing Practice in Rwanda:

x. Enhancing Maternal and Newborn Health June 2017

xi. Barriers to Attendance at Continuing Nursing Education Presentations

xii. Nancy Brace, RN, MA; Becky Sheely, RN, BSN; Douglas A Conner, PhD; Cynthia A Martin, RN, BSN, AE-C 
Questionnaire

\section{Appendix}

Assessment on the Relationship/ Association between CNE and Quality Patients' Services

Introduction

I Rozina Amir Ali student of MBA_in _ JSMU developed this questionnaire to conduct a study on said theme/ area as part of my MBA thesis. I would request you to please take out a few minutes to fill this questionnaire.

\begin{tabular}{|c|c|c|}
\hline Name (optional) & & Age \\
\hline Sex & 1). Male & Name of Hospital/ health care institute \\
& 2). Female & \\
\hline 3esignation & & Department \\
\hline
\end{tabular}

Table 1

\begin{tabular}{|c|c|c|c|c|c|}
\hline$\overline{\text { A.1 }}$ & $\begin{array}{l}\text { For how many years you have } \\
\text { been working as health } \\
\text { professional? }\end{array}$ & $\begin{array}{l}\text { 1). } 1-2 \\
\text { 2). } 3-4 \\
\text { 3). } 4-6 \\
\text { 4). } 7-8 \\
\text { 5). } 9-10 \\
\text { 6). } 11-15 \\
\text { 7). } 16-20 \\
\text { 8). Others }\end{array}$ & A.2 & $\begin{array}{l}\text { Have CME credit } \\
\text { hour has fulfilled } \\
\text { your education } \\
\text { requirement? }\end{array}$ & $\begin{array}{l}\text { 1). Yes } \\
\text { 2). No }\end{array}$ \\
\hline A.3 & $\begin{array}{l}\text { Did you make the practice } \\
\text { change as a result of getting } \\
\text { CNE? }\end{array}$ & $\begin{array}{l}\text { 1). Yes } \\
\text { 2). No }\end{array}$ & A.4 & $\begin{array}{l}\text { If Yes, Describe the } \\
\text { impact of change on } \\
\text { patient care }\end{array}$ & \\
\hline A.5 & $\begin{array}{l}\text { If answer of A3 is No. then ask, } \\
\text { please indicate any/ all } \\
\text { barriers you encountered } \\
\text { when making the change in } \\
\text { practice. }\end{array}$ & $\begin{array}{l}\text { 1). Lack of resources (financial, } \\
\text { staffing) } \\
\text { 2). Lack of time } \\
\text { 3). System related } \\
\text { 4). Patient is not complying } \\
\text { with change } \\
\text { 5). Other: }\end{array}$ & A.6 & $\begin{array}{l}\text { Do you feel that your } \\
\text { patient(s) get benefit } \\
\text { out of your skills } \\
\text { acquainted through } \\
\text { having CME } \\
\text { education }\end{array}$ & $\begin{array}{l}\text { 1). Yes } \\
\text { 2). No }\end{array}$ \\
\hline A.7 & $\begin{array}{l}\text { Does your hospital/ institution } \\
\text { provide you an opportunity to } \\
\text { attend CNE outside of your } \\
\text { institution }\end{array}$ & $\begin{array}{l}\text { 1).Yes } \\
\text { 2). No }\end{array}$ & A.8 & $\begin{array}{l}\text { If No, what are the } \\
\text { reasons? }\end{array}$ & \\
\hline A.9 & $\begin{array}{l}\text { Do you get sufficient hour to } \\
\text { grasp which you have taught } \\
\text { during CNE }\end{array}$ & $\begin{array}{l}\text { 1). Yes } \\
\text { 2). No }\end{array}$ & & & \\
\hline
\end{tabular}

Table 2: Please Circle Your Response (se)

\begin{tabular}{|l|l|l|l|l|l|l|}
\hline S No & Question/ Statement & $\begin{array}{c}\text { Strongly Agree } \\
\text { (1) }\end{array}$ & $\begin{array}{c}\text { Agree } \\
\text { (2) }\end{array}$ & $\begin{array}{c}\text { No Opinion/ Neutral } \\
\text { (3) }\end{array}$ & $\begin{array}{c}\text { Disagree } \\
\text { (4) }\end{array}$ & $\begin{array}{c}\text { Strongly } \\
\text { Disagree(5) }\end{array}$ \\
\hline 1 & $\begin{array}{l}\text { CNE actively promotes } \\
\text { improvements in health care } \\
\text { system }\end{array}$ & & & & & \\
\hline 2 & $\begin{array}{l}\text { CNE is beneficial for healthcare staff } \\
\text { to promote life-long learning } \\
\text { process }\end{array}$ & & & & & \\
\hline 3 & $\begin{array}{l}\text { CME improves healthcare staff's } \\
\text { professional competence }\end{array}$ & & & & & \\
\hline 4 & $\begin{array}{l}\text { CNE improves participants prior } \\
\text { skills and knowledge }\end{array}$ & & & & & \\
\hline 5 & $\begin{array}{l}\text { CNE helps to improve patients care } \\
\text { and satisfaction }\end{array}$ & & & & & \\
\hline 6 & $\begin{array}{l}\text { CNE promotes accountability and } \\
\text { transparency towards patients' care }\end{array}$ & & & & & \\
\hline
\end{tabular}

Table 3: Instructions: for Each Statement, Circle the Appropriate Number to Indicate Your Response 